Article

\title{
Recent Developments and Current Status of Commercial Pro- duction of Fuel Ethanol
}

\author{
Tuan-Dung Hoang 1,* and Nhuan Nghiem ${ }^{2}$
}

1 Department of Environmental Security and Technology, Hanoi School of Business and Management, Vietnam National University, Hanoi, Vietnam; tuandung@vnu.edu.vn

2 Biosystems Engineering Program, Department of Environmental Engineering and Earth Sciences, Clemson University, USA; nnghiem@g.clemson.edu

* Correspondence: tuandung@vnu.edu.vn; Tel.: (+84) 936414637

\begin{abstract}
Ethanol produced from various biobased sources (bioethanol) has been gaining high attention lately due to its potential to cut down net emissions of carbon dioxide while reducing burgeoning world dependence on fossil fuels. Global ethanol production has increased more than sixfold from 18 billion liters at the turn of the century to 110 billion liters in $2019(1,2)$. Sugar cane and corn have been used as the major feedstocks for ethanol production. Lignocellulosic biomass has recently been considered as another potential feedstock. This paper reviews recent developments and current status of commercial production of ethanol across the world. The review includes the ethanol production processes used for each type of feedstock, both currently practiced at commercial scale and newly developed technologies, and production trends in various regions and countries in the world.
\end{abstract}

Keywords: fuel ethanol; renewable energy; biobased feedstocks; lignocellulosic biomass; fermentation process; processing options; commercialization; production status; climate change; environmental security

\section{Introduction}

Ethanol $\left(\mathrm{C}_{2} \mathrm{H}_{6} \mathrm{O}\right)$ is an organic chemical compound, a simple liquid alcohol that is formed from the fermentation of sugars in their natural occurrences or being derived from starch-rich grains or lignocellulosic feedstocks. Ethanol is also called ethyl alcohol, grain alcohol, drinking alcohol, or simply alcohol, and is used as medical, recreational, chemical solvent, feedstocks, fuel application and source. It is found out that ethanol when blended with $95 \%$ gasoline can minimize about $90 \% \mathrm{CO}_{2}$ and $60-80 \% \mathrm{SO}_{2}(40)$. This helps the world solve the problems of air pollution, reduces greenhouse gases or climate change and maintains environmental security. Furthermore, the increase of liquid fuels supplying the energy demand with regards to economic and environmental concerns make ethanol a good energy alternative for many countries. There are commonly three groups of materials that can be used for manufacturing ethanol, which are: a) feedstocks which contain substantial amounts of readily fermentable sugars, b) starches and fructans, and c) cellulosic materials. The objective of this study is therefore to investigate the recent development of ethanol production in various countries around the world. The study also examines current technologies in ethanol production and the status of commercial production of fuel ethanol in various countries.

\section{Production Technologies}

Three types of feedstock can be used for ethanol production. These include sugarbased feedstocks (sugar cane, sugar beet), starched-based feedstocks (corn, barley, wheat, other grains), and lignocellulosic feedstocks (agricultural residues, forest residues, dedicated energy crops, municipal solid wastes). 


\subsection{Sugar-based feedstocks}

The juice extracted from sugar cane has been used for ethanol production. Part of the juice is used for sugar manufacture in an adjacent sugar manufacturing plant and the remain-ing is used for ethanol production such as the case of Brazil, which is the second largest ethanol producer in the world. Juice extraction can be used through either crushing (roll mills) or diffusion (diffuser). The decision to produce sugar and/or ethanol is made by individual plants from harvest to harvest. This is a very important issue since once the producing units adjust their plants to produce a set ratio of sugar/ethanol in a given year, it is very difficult to change during the harvest season (3). Bagasse, which is the solid residue obtained after juice extraction, has been combusted to generate energy for internal uses, but also has the potential as a lignocellulosic feedstock for additional ethanol production. Molasses, which is a by-product of sugar cane processing, can also be used for ethanol production.

Typically sugarcane contains $12-17 \%$ total sugars on a wet weight basis with 68-72 $\%$ moisture. About $90 \%$ of the sugars are sucrose with glucose and fructose making up the balance. All these three sugars are readily fermentable by the yeast Saccharomyces cerevisiae to produce ethanol. During the fermentation process, the yeast produces the enzyme invertase and uses it to convert sucrose to glucose and fructose. Ethanol production by S. cerevisiae is carried out via the glycolytic pathway (also known as the EmbdenMeyerhof-Parnas or EMP pathway). In the simplest form, production of ethanol from glucose can be expressed by the following equation:

$$
\begin{gathered}
\mathrm{C}_{6} \mathrm{H}_{12} \mathrm{O}_{6}+2 \mathrm{P}_{\mathrm{i}}+2 \mathrm{ADP} \\
\text { Glucose }
\end{gathered} \rightarrow \begin{aligned}
& 2 \mathrm{C}_{2} \mathrm{H}_{5} \mathrm{OH}+2 \mathrm{CO}_{2}+2 \mathrm{ATP}+2 \mathrm{H}_{2} \mathrm{O} \\
& 2 \text { ethanol }+2 \text { carbon dioxide }+ \text { energy }
\end{aligned}
$$

According to the above equation, the maximum theoretical yield of ethanol produced from 1 gram of glucose is $0.511 \mathrm{~g}$ ethanol. In practice, it is observed that the actual yield is always lower since not all of the glucose consumed is converted to ethanol.

The fermentation process can be either batch/fedbatch or continuous. The MelleBoinot batch process, which was developed in the 1930's, is most commonly used. Its main characteristic is total yeast recycle, normally by centrifugation. The very high yeast densities $(10-14 \% \mathrm{w} / \mathrm{v})$, which are obtained by yeast recycle, allow reduced growth, high ethanol yield and very short fermentation time $(6-10 \mathrm{~h})$. The continuous process with cell recycle was developed in the 1980's to replace the batch process (5). The majority of the commercial plants in Brazil, however, still employ the batch/fed-batch process. The ethanol produced is recovered by distillation followed by molecular sieve or other dehydration technology to produce anhydrous ethanol (>99.5\%). The stream coming out at the bottom of the distillation columns is called vinasse. Vinasse normally is spread on the sugar cane fields for use as irrigation water and fertilizer. However, this practice may cause extensive pollution of the environment due to the high organic contents, dark color, dissolved solids and other compounds that are toxic under certain conditions. Methods for treatment of vinasse prior to their disposal have been developed (6).

Sugar beet is grown in regions with temperate climates and is one of the main feedstocks used for ethanol production in Europe. Sugar beet has a conical, white and fleshy root, which serves as a reservoir for sugar. The root contains about $75 \%$ water and between $15 \%$ and $21 \%$ total sugars (wet weight basis). Because of the similarities in chemical compositions of sugar solutions extracted from sugar cane and sugar beet, those obtained from sugar beet also can be fermented to ethanol by industrial yeast at high efficiencies. The fermentation processes are very similar in both cases. Like sugar cane, ethanol production from sugar beet can be integrated with sugar production.

\subsection{Starch-based feedstocks}

Corn is used almost exclusively for ethanol production such as the case in the United States where ethanol is produced from corn by either the wet-milling or dry-grind process. 
The US is the largest producer of ethanol in the world where the majority of the commercial ethanol plants use the dry-grind process. Ethanol can also be produced from other grains by the dry-grind process.

In the dry-grind process, after grinding, water and a thermostable $\alpha$-amylase are added to the ground corn. In the next step, which is called pre-liquefaction, the slurry then is brought up to $60-70^{\circ} \mathrm{C}$ (warm cook) or $80-90^{\circ} \mathrm{C}$ (hot cook). The slurry, which is referred to as the corn mash, is held at these temperatures for about 30-45 min. The swelling and hydration of the starch granules cause dramatic increase of the slurry viscosity and loss of crystallinity of the granule structures. In the next step, which is called liquefaction, the mash is maintained at $85-95^{\circ} \mathrm{C}$ for a period of time or forced through a continuous jet cooker at $140-150^{\circ} \mathrm{C}$. At the end of the liquefaction, starch is hydrolyzed to short-chain dextrins (two to four glucose units). The mash temperature is lowered to $32^{\circ} \mathrm{C}$ and the mash $\mathrm{pH}$ is switched to approximately $\mathrm{pH} 4.5$; the mash then is stored in a fermentor. Glucoamylase and the yeast cultured from the yeast propagation tank are also added. Nitrogen source might come from urea. The process combining enzymatic hydrolysis and fermentation is called simultaneous saccharification and fermentation (SSF). The SSF is a batch process which typically is run for about 50-60 h. The final ethanol concentration is about $15 \%(\mathrm{v} / \mathrm{v})$. Commonly used commercial glucoamylase formulations also contain proteases. These enzymes break down organic nitrogen sources in the corn slurry and release additional nutrients, which help to improve fermentation efficiency and ethanol yield. The ethanol produced is recovered by distillation followed by molecular sieve as described previously. The bottom stream from the distillation columns is called stillage. This stream is dried to a moisture content of about $10 \%$ to produce distillers dried grains with solubles (DDGS) which are sold or used as animal feed. DDGS is the most important co-product in a dry-grind ethanol plant. The other co-products are the carbon dioxide produced in the fermentation process and corn oil.

In the wet-milling process, corn grains are soaked in water 0.1 to $0.2 \% \mathrm{SO}_{2}$ at $52 \cdot \mathrm{C}$ (125.F) for 24 to 40 hours. After this so-called steeping step, the softened grains are then ground gently to break up the kernels. The less dense germs, which contain about 40 to $50 \%$ oil, are recovered in a hydrocyclone system and processed into value-added co-products. After the germs are removed, the slurry was subjected to further grinding to loosen the starch and gluten from the remaining fiber. The slurry is screened to remove the fiber, which then is washed and pressed to about $60 \%$ moisture. The water from the steeping step, which is called light steep water (LSW), is concentrated in evaporators to produce heavy steep water (HSW). The HSW is dried together with the recovered fiber and the resultant product is sold to the livestock industry as corn gluten feed, which typically contains about $21 \%$ proteins. After fiber removal, the gluten, which is lighter, is separated from the starch in a centrifuge. The recovered gluten is concentrated from, cooled to $35^{\circ} \mathrm{C}$ and filtered on a rotary vacuum filter to produce a gluten cake of $60 \%$ moisture. The cake is dried to $10 \%$ moisture to produce corn gluten meal. This feed product contains at least $60 \%$ protein and $1 \%$ fat, and up to $3 \%$ fiber. It is used in poultry feed because of its high protein and xanthophyll and low fiber contents.

The starch is washed and processed through a series of up to 14 hydrocyclones to remove impurities. The final product, which is $99.5 \%$ pure starch, then is used for ethanol fermentation in dedicated plants or processed further to produce modified starch, corn syrup (CS) and high fructose corn syrup (HFCS) in integrated plants (4).

The hydrolysis of starch to produce glucose can be expressed by the following equation

$$
\left(\mathrm{C}_{6} \mathrm{H}_{10} \mathrm{O}_{5}\right)_{n}+\mathrm{n} \mathrm{H} \mathrm{H}_{2} \mathrm{O} \rightarrow \mathrm{n} \mathrm{C}_{6} \mathrm{H}_{12} \mathrm{O}_{6}
$$

where $\mathrm{n}$ is the number of glucose residues in the starch molecule.

In a starch molecule, $\mathrm{n}$ is a very large number. The theoretical yield or conversion factor for glucose is $1.11 \mathrm{~g}$ glucose $/ \mathrm{g}$ starch. And the theoretical yield for ethanol is $0.57 \mathrm{~g}$ ethanol/g starch.

In the United States, it is commonly accepted that one bushel of corn (56 lbs or 25.4 $\mathrm{kg}$ ) of about $15 \%$ moisture processed by the dry-grind process will produce 2.9 gallons 
(or 11.0 l) denatured ethanol, $15.2 \mathrm{lbs}$ (or $6.9 \mathrm{~kg}$ ) distillers grains animal feed (10\% moisture), $0.8 \mathrm{lbs}$ (or $0.36 \mathrm{~kg}$ ) distillers corn oil, and $1.1 \mathrm{lbs}$ (or $0.5 \mathrm{~kg}$ ) captured carbon dioxide (7).

Many efforts have been made to improve ethanol production with the focus on the dry-grind process. These improvements are discussed briefly below.

- $\quad$ Syngenta developed the Enogen ${ }^{\circledR}$ corn hybrids containing $\alpha$-amylase, which helps to reduce the viscosity of the corn mash and reduce/eliminate the need of externally added $\alpha$-amylase (8).

- $\quad$ Lallemand, in collaboration with other companies, developed the TransFerm ${ }^{\circledR}$ Yield+ S. cerevisiae, which produces the glucoamylase needed for starch hydrolysis and improves ethanol yield up to $4 \%$ as a result of $30 \%$ reduction in glycerol synthesis. The reduced glycerol levels are not expected to have an adverse effect on the yeast tolerance of osmotic stress caused by ethanol (9). The newer strain, TransFerm CV5, is a genetically modified yeast strain that produces high levels of glucoamylase and trehalase expression, which can meet between $80 \%$ and $100 \%$ of the enzymes required in fermentation (10).

- Novozymes developed the glucoamylase-producing Innova Drive S. cerevisiae, which could tolerate $98^{\circ} \mathrm{F}\left(36.7^{\circ} \mathrm{C}\right), 37 \%$ solid loading, and $6 \mathrm{~g} / \mathrm{L}$ organic acids (11). Other strains of the Innova product series also have been developed with improved tolerance of heat (up to $40^{\circ} \mathrm{C}$ ) and resistance to high levels of solids and high concentrations of glucose, ethanol and organic acids (12).

Several companies, which include Poet (formerly Broin), Cereal Process Technologies (CPT), Buhler, Renessen, and FWS Technologies, have developed dry fractionation processes. All dry corn fractionation processes are fundamentally similar. Prior to the conventional dry-grind process, corn is ground and subsequently fractionated into fermentable and non-fermentable fractions. Only the fermentable fraction is used in the dry-grind process for ethanol production. The non-fermentable fractions are separated by various methods and recovered as bran and germ co-products, which are sold for use in animal feeds. The DDGS obtained after ethanol recovery has higher protein but lower oil and fiber contents compared to the product obtained in a traditional dry-grind process without corn fractionation (4).

- D3MAX developed a process for conversion of corn fiber and the unconverted starch in the stillage to additional ethanol. The D3MAX process is a "bolt-on" process, which means it can be added to an existing dry-grind ethanol plant. The key step of this process is the pretreatment of the wet cake obtained by centrifugation of the stillage with dilute acid. The pretreated wet cake then is subjected to enzymatic hydrolysis and fermentation, which uses a genetically modified yeast capable of utilizing both glucose and xylose for ethanol production. (13).

- Quad County Corn processors (QCCP) developed the Cellerate process, which is also a bolt-on process. This process is very similar to the D3MAX process, except that the whole stillage rather than the wet cake is pretreated with dilute acid prior to enzymatic hydrolysis and fermentation. It was reported that when Enogen $®$ corn is used (in collaboration with Syngenta), compared to the traditional dry-grind process using regular corn, the Cellerate process resulted in $6 \%$ increase in ethanol yield, $15 \%$ increase in throughput, and $20 \%$ reduction in energy consumption, and produced $1.6 \mathrm{lbs}(0.73 \mathrm{~kg})$ corn oil per bushel plus a DDGS with higher protein and lower fiber (14).

- $\quad$ Edeniq developed the Intellulose ${ }^{\circledR}$ process using their proprietary enzyme mixtures to produce ethanol from the previously unconverted starch and fibers. It was reported that the technology resulted in a $2-4.5 \%$ increase in ethanol production. Edeniq also developed an analytical technique to directly measure ethanol production from the lignocellulosic fractions in the corn kernel $(15,16)$.

\subsection{Lignocellulosic feedstocks}


Lignocellulosic feedstocks are also referred to as lignocellulosic biomass or simply biomass. In this review, the term biomass is used. Biomass consists of three main components, which are cellulose, hemicellulose, and lignin. There are two options for the conversion of biomass to ethanol. In the first option, cellulose and hemicellulose are hydrolyzed to fermentable sugars, which are subsequently fermented to produce ethanol. In the second option, the biomass is taken through a process called gasification. In this process, the biomass is heated with no oxygen or with oxygen significantly below the normally required for complete combustion. The product is a gas which is mostly $\mathrm{CO}$ and $\mathrm{H}_{2}$. The gaseous product is called synthesis gas or syngas which can be converted to ethanol via either fermentation or chemical catalysis processes. The first option normally is referred to as the sugar platform and the second as the syngas platform. In the sugar platform, only the carbohydrate components of biomass are used for ethanol production, whereas lignin is considered as a waste and normally is burned to generate energy. In the syngas platform, all three components are used for ethanol production.

Hydrolysis of cellulose and hemicellulose can be performed with either chemicals or enzymes. The chemicals used for the hydrolysis of cellulose and hemicellulose include concentrated (>70 \%) $\mathrm{H}_{2} \mathrm{SO}_{4}$, which is used in the Arkenol process (17) and the Biosulfurol process (18), supercritical fluid, which is used in the Renmatix process (19), and $\gamma$ valerolactone (GVL), which is used in the GlucanBio process (20). A process called pretreatment is required before the cellulose and hemicellulose components of biomass can be effectively hydrolyzed by enzymes. The pretreatment process is needed because this process improves the rates of the subsequent enzymatic hydrolysis and increases the yields of the fermentable sugars. Some authors have been thoroughly reviewing the biomass pretreatment processes recently (4). The fermentable sugars obtained in enzymatic hydrolysis of cellulose and hemicellulose consists mostly of glucose and xylose, plus arabinose, galactose, and mannose in significantly smaller amounts. Since the yeast $S$. cerevisiae can only metabolize glucose, genetically engineered strains capable of utilizing both glucose and xylose for ethanol production have been developed for commercial applications (21).

Various types of commercial gasifiers are suitable for biomass gasification. The impurities and inhibitory compounds in the syngas produced have to be removed before the syngas can be used for ethanol production in either the microbial or catalytic process. The microorganisms that have been considered as most promising candidates for commercial syngas ethanol fermentation include Clostridium ljungdahlii, Clostridium ragsdalei, Clostridium carboxydivorans, Clostridium coskatii, Clostridium autoethanogenum, and Alkalibaculum bacchi. Some of these species only produce ethanol and acetic acid, whereas others can produce additional products, which include butyric acid, butanol, and 2,3-butanediol as mentioned previously.

One of the key issues of ethanol production from biomass via fermentation, either in the sugar platform or the syngas platform, is the low achievable final ethanol concentration. Since it is most likely that the ethanol produced will be recovered by distillation, which is a very energy-intensive process, the minimum acceptable ethanol concentration in the input to the distillation unit is $50 \mathrm{~g} / \mathrm{L} \mathrm{(4).}$

\section{Global Ethanol Production}

It is estimated that currently $60 \%$ ethanol is produced from corn, $25 \%$ from sugar cane, $3 \%$ from wheat, $2 \%$ from molasses, and the rest from other grains, cassava and sugar beets. The top five ethanol producers are the United States, Brazil, China, the European Union $(\mathrm{EU})^{*}$, and India, which contribute $48.2 \%, 26.7 \%, 8.3 \%, 4.8 \%$ and $2.3 \%$, to the total global production, respectively (22). Ethanol production from the individual nations with significant annual ethanol outputs are reviewed in the following sections. *The EU in this review refers to the union of 28 members, i.e. before the exit of the United Kingdom. 


\subsection{North America}

\subsubsection{The United States}

In the US, ethanol produced from corn reached 6.5 billion gallons in 2007 and in 2012 this total doubled to approximately 13.2 billion gallons. In 2018 the U.S. exported a total of 6.5 billion ethanol liters, expanding the share of world exports of ethanol to $61 \%$. Most ethanol produced in the United States is from starch-based crops by dry or wet-mill processing technologies. In 2020, there were 208 ethanol production plants in the United States with a total installed capacity of 17.44 billion gallons per year ( 66.0 billion liters per year). The total production in 2020 was 13.8 billion gallons (52.2 billion liters), which represented a $12.7 \%$ decrease from the production total of 15.8 billion gallons (59.8 billion liters) in the previous year $(7,23)$. The decrease in ethanol production was mainly caused by the reduction in transportation fuel demand, which was the direct consequence of the COVID-19 pandemic. Whereas a number of plants were shut down, some other plants modified the production process to produce an ethanol product which is suitable for use in hand sanitizers to cope with the economic downturn. It is expected that production of ethanol will go back up in 2021. The ethanol co-products generated in 2020 included 29.4 million metric tons (MT) distillers grains, 3.1 million MT corn gluten feed, 0.6 million MT corn gluten meal, 1.5 million MT corn oil and 2.1 million MT captured $\mathrm{CO}_{2}$. Corn was the major feedstock, which accounted for $93.2 \%$ of the total ethanol production in 2020 . Other feedstocks included sorghum, corn fiber, waste sugars, waste starch and lignocellulosic biomass. The interest in lignocellulosic biomass as a potential feedstock for ethanol production continued to be strong. Despite previous failures by large corporations like Poet and DuPont, New Energy Blue announced in July 2021 the plan to construct a full-scale ethanol biorefinery, which would consume 250,000 MT per year agricultural residues generated locally for ethanol production. The proposed plant would use the Inbicon process, which would also produce a lignin co-product for use as a solid biofuel and a natural binder and possibly xylitol as a specialty chemical with potential food applications (24, 25).

\subsubsection{Canada}

Canada is a net importer of ethanol since the volume consumed in Canada generally exceeded the ethanol this country produced. In 1980, Canadian produced merely 80001 but in 2010 the annual ethanol production of Canada reached 1.9 billion litres. In 2019, ethanol consumption in Canada reached 3.33 billion liters compared to 2 billion liters in production. However, ethanol production in Canada has grown in recent years largely due to changes in feedstocks and increased capacity at existing ethanol facilities in Canada.

In 2020, Canada was ranked as the sixth largest ethanol producer in the world. The ethanol production in Canada represented $1.6 \%$ of the total global production. The two major feedstocks used for ethanol production were corn and wheat, which contributed 1534.3 million liters and 360.7 million liters, respectively (22). Winter barley has been considered as a potential feedstock for ethanol production. However, this grain has not been used in any ethanol production plant.

\subsection{South America}

\subsubsection{Brazil}

Brazil continued to be the second largest ethanol producer in the world. From 2009 to 2019 Ethanol fuel production in Brazil (in million cubic meters). In 2019, Brazil ethanol production including anhydrous and hydrous ethanol amounted to more than 35.3 million cubic meters, an increase of nearly seven percent in comparison to a year of 2018. This is the highest volume of fuel ethanol production volume that Brazil has produced in the decade. In Brazil, sugarcane bagasse is commonly used as boiler fuel to produce energy to supply sugar mills. This is to minimize the energy costs and also as an alternative to the utilization of biomass left over. 
In 2020, the ethanol production in Brazil represented $26.7 \%$ of the total global ethanol production (22). There were 360 first-generation (sugar cane, corn) ethanol plants in Brazil in 2020 with a total nameplate capacity of 42,800 million liters. However, only $67 \%$ of the capacity was used. There were three plants that used lignocellulosic feedstock with a total nameplate capacity of 127 million liters. In 2020, these second-generation ethanol plants only operated at $25 \%$ capacity. The feedstocks included sugar cane (326.6 million MT), corn (6.0 million MT) and bagasse (178,000 MT). The total ethanol production in 2020 was 31.35 billion liters, which included 32 million liters produced from lignocellulosic feedstock (bagasse). The 2020 ethanol production was about $16 \%$ lower compared to the previous year (37.38 billion liters). The decrease in ethanol production in 2020 was mainly caused by the diversion of sugar cane juice toward more sugar production in sugar-ethanol plants. The co-products included 120.1 million MT bagasse, 1.88 million MT DDGS and 108,000 MT corn oil. The traditional feedstock for first-generation ethanol production in Brazil is sugar cane. However, corn has become an important feedstock and its use for ethanol production has steadily gained ground. In 2020, 2.5 billion liters ethanol was produced from corn, which was 1.17 million liters higher than the previous year. The Corn Ethanol National Union (UNEM) predicted that corn ethanol production would reach 8 billion liters by 2028. There currently are 11 corn ethanol plants, which include nine fullplant types (corn only) and 2 flex-plant types (corn and sugarcane). Two full-plants and one flex-plant are currently under construction (26).

\subsubsection{Argentina}

In 2020, Argentina was ranked $8^{\text {th }}$ in the world with a contribution of $1.0 \%$ toward the total global ethanol production (22). There were 22 ethanol plants with a total nameplate capacity of 1,580 million liters per year. The ethanol plants, however, were operated only at $55.1 \%$ capacity. Corn and molasses were used as feedstocks at 1.09 million MT and 1.70 million MT, respectively. The total ethanol production was 870 million liters, which was significantly lower than the total production in the previous year $(1,073$ million liters). The DDGS co-product was also produced at 345,000 MT (27).

\subsubsection{Colombia}

Colombia was ranked $13^{\text {th }}$ in the world in 2020 with a contribution of $0.44 \%$ toward the total global ethanol production (22). The country had six ethanol plants, which used sugar cane as the only feedstock. The total nameplate capacity of the plants was 540 million liters. These plants were run at only $73.1 \%$ capacity in 2020 . The total ethanol production in 2020 was 395 million liters with 1.34 million MT bagasse co-product. Five of the six ethanol plants were directly linked to the sugar production plants. The bagasse obtained after juice extraction was used to generate energy for internal use in these plants. Most ethanol plants in Colombia were energy self-sufficient and even generated surplus energy to sell to the national grid (28).

\subsection{Europe}

\subsubsection{The European Union}

The total ethanol production in the EU in 2020 was $4.8 \%$ of the total global production (22). The major feedstocks used for ethanol production were sugar beets (7.45 million MT), corn (6.35 million MT), and wheat (2.64 million MT). Other first-generation feedstocks were triticale (1.04 million MT), rye (520,000 MT) and barley (450,000 million MT). Wheat was predominantly used in Belgium, Germany, France and the UK. Corn was the preferred feedstock in Hungary, where corn was abundantly available, and in the Netherlands, Spain, and the UK, where the majority of corn came from the Ukraine to provide the feedstock for ethanol plants, which are located near seaports. The inland ethanol plants in Spain used a combination of corn and barley as the feedstock. Sugar beets and their derivatives were used for ethanol production in France, Germany, the UK, the Czech 
Republic, Belgium and Austria. The usage of lignocellulosic feedstocks in 2020 was doubled to 200,000 MT compared to the previous year. There were 57 first-generation ethanol plants with a total namplate capacity of 8.15 billion liters, which were operated at $58 \%$ capacity. There were also 3 lignocellulosic ethanol plants with a total nameplate capacity of 90 million liters. However, these second-generation ethanol plants were operated at only $28 \%$ capacity. Five other lignocellulosic ethanol plants were under construction in Finland (sawdust, 10 million liters per year), Italy (biomass, 28 million liters per year), Austria (wood sugars, 30 million liters per year), Romania (wheat straw, 65 million liters per year) and Bulgaria (corn stover, 50 million liters per year). All of those plants are expected to be in operation soon. The ethanol production in the EU in 2020 was 5.47 billion liters. Due to the COVID-19 pandemic, ethanol consumption in the EU has decreased by $10.1 \%$. However, this number is still was slightly lower than the $13.0 \%$ decrease in gasoline consumption. According to the European Union Biofuels Annual Report (2021), the co-products were 3.33 million MT DDGS and 188,000 MT corn oil (29).

\subsection{Asia and rest of the world}

\subsubsection{Vietnam}

Vietnam is an agriculture-based country and has abundant natural resources for renewable power development. However, the pace of renewable energy development including ethanol production is not yet rapid due to barriers such as the small size of the country's economy, the lack of financial capacity, advanced technologies and human resources. Institutional barriers such as market-controlled mechanisms and unstable supporting policies also limit the development of renewable power sectors (30).

In terms of ethanol development, due to the economic development, Vietnam has consumed lots of gasoline in recent years. USDA estimated gasoline consumption of Vietnam is approximately 4-5 percent per year. In the first quarter of 2020, Vietnam spent about $\$ 2.5$ billion on importing crude oil and petroleum products, including ethanol, in addition to its production (31). Since 2007 ethanol supporting regulations have gradually increased, however, the commercialization and sales of five percent ethanol blended gasoline (E5) was pushed back to 2018 due to a lack of understanding of the environmental benefits of ethanol blended gasoline by consumers, together with some persistent rumors and myths that usage of ethanol might harm vehicle engines.

\subsubsection{Korea}

Korea is the 7th ranked $\mathrm{CO}_{2}$ emitter in the world and like other countries is concerned about its high $\mathrm{CO}_{2}$ emissions and its dependence on imported crude oil. All of the oil Korea consumes is imported from foreign countries. South Korea is a main importer of U.S. ethanol, with a total volume of 263.84 million liters $(24.7$ million bushels in corn equivalent) in 2017, 2018. In the mid-1990s, fuel-use production of first-generation ethanol (1G ethanol) in Korea using imported cassava as a feedstock was initiated. The Korea Ministry of Knowledge Economy (KMKE) announced an action plan to increase the biofuels in the transport sector from 0.2 million $\mathrm{kL}$ in 2008 to 5 million $\mathrm{kL}$ by 2030. (32).

\subsection{China}

From 2004 to 2016, China produced ethanol with an average production rate of 16.8 percent. In 2017, China had an ethanol production of 2.8 million tonnes. In 2018, China produced 6.6 million tonnes, making it the fourth-largest ethanol producing country/region in the world, after the United States, Brazil, and the European Union. China set a policy that gasoline supplies across the country were required to be blended with ethanol by 2020. Reuters summarised that China aimed to produce a capacity of 15 million tonnes, almost triple its current ethanol production capacity by 2020 in order to keep up with growing demands for cleaner fuels (33). The target would exceed the estimated domestic production capacity of China and the country would need to import ethanol from 
foreign countries such as the United States and Brazil. USDA's China biofuel annual reported that corn is China's main feedstock (called generation 1), currently accounting for 64 percent of total output for China's ethanol production (34).

\subsubsection{India}

India ranked $6^{\text {th }}$ among leading ethanol producers in the world. In 2020, India still remained one of the biggest importers of the United States' ethanol, with a market share of 99 percent. With Modi's "self-resilient" strategies, India sets its ambitious goal of E-20 by 2025 while retaining its immediate goal of E-10 by 2022. India has a total installed ethanol capacity of 5 billion liters, of which molasses-based distilleries constitute 4.2 billion liters, or 85 percent of the overall production capacity while grain-based distilleries constitute 750 million liters (equivalent to 15 percent).

Formerly, ethanol in India could only be produced from molasses or sugar juice. However, India's existing ethanol is produced from a variety of feedstocks like cereals (rice, wheat, barley, maize, and sorghum). In 2020, an estimated 2.98 billion liters of ethanol was produced from molasses. In 2021, India's ethanol production is forecast at 3.17 billion liters, $7 \%$ above 2020 due to surplus sugarcane production and 2021 average ethanol blending rate in gasoline of India is estimated at 7.5 percent, due to accelerated government efforts to divert more feedstock toward ethanol (35).

\subsubsection{Thailand}

Thailand is the $7^{\text {th }}$ biggest ethanol producer in the world. Thailand consumed 1,500 million liters of ethanol in 2020. Thailand's 20-year Alternative Energy Development Plan or AEDP (2018 - 2037) targeted 1,985 million liters for ethanol in 2021, and 2,700 million liters for ethanol consumption in 2037. Molasses are the primary feedstock for ethanol production in Thailand. Molasse supplies in Thailand have been tight due to reduced sugarcane production for the second consecutive year. Ethanol demand is primarily expected to be fulfilled by cassava-based ethanol in Thailand (36).

\subsubsection{Australia}

Australia's ethanol consumption is forecast to remain stable in 2020 at only $1.4 \%$ of the gasoline. Ethanol Australia is primarily produced as a biofuel for passenger and commercial vehicles and also for alcoholic beverage, industrial chemicals, and solvents used in pharmaceutical and cosmetic applications. In spite of large feedstock availability, Australia's ethanol production volumes remain small because there is no nationwide fuel ethanol program. In Australia only two states, which are New South Wales and Queensland, have mandates with a fuel ethanol program, and have the highest consumption of ethanol blended fuel.

In New South Wales, Manildra is the largest ethanol producer with a capacity of over $300 \mathrm{ML}$. In this Manildra plant wheat starch is processed through an integrated process which separates the gluten and processes the remaining starch into a range of food and industrial-grade starches, glucose syrups, and ethanol products. In Queensland, a plant at Dalby producing ethanol from starch-based feedstock is operated by United Petroleum. This Dalby bio-refinery is located in a sorghum growing region in the Darling Downs and processes up to 0.2 million metric tons (MMT) of sorghum grain a year from local growers, and this plant can produce $80 \mathrm{ML}$ of fuel-grade ethanol. At full capacity, this biorefinery can also produce $830,000 \mathrm{MT}$ of wet distillers grain, which is used for animal feed supplements (37).

\subsubsection{Zimbabwe and other African countries}

Zimbabwe has adopted ethanol petrol blending regulations. Two mills in Zimbabwe, namely Triangle Sugar and Hippo Valley, were installed. In 2010, the Triangle mill resumed producing ethanol after refurbishing its ethanol plant with a capacity of 27 million 
litres per year. The government of Zimbabwe also initiated the Chisumbanje sugar/bioethanol project with an aim of using 10,000 hectares of sugarcane for this project. In March 2012, owners of this project halted production because the plant was running out of storage space. In Zimbabwe, some oil companies were only selling E10 at a few of their filling stations (38).

In other African countries, lead additives are still heavily used in gasoline and where sugarcane production cost is high, ethanol can be a cheap source of octane in gasoline. It is estimated that in Africa, to replace all the lead used in African gasoline, this would require Africa to produce about $20 \%$ of the amount of ethanol currently produced in Brazil, and would require the shift of some sugar production to ethanol production. African countries that could replace lead with ethanol using primarily their by-product molasses production include Zimbabwe, Kenya, Egypt, Zaire, Zambia, Sudan, Swaziland, and Mauritius at a more modest scale (39).

The annual world fuel ethanol production in the last three years together with the production by the individual countries that contributed to at least $1 \%$ of the total production are summarised in Table 1.

Table 1. Annual world fuel ethanol production (mil. litters) (Source: Renewable Fuels Association analysis of public and private data sources (41)).

\begin{tabular}{|c|c|c|c|c|}
\hline Region & 2018 & 2019 & 2020 & $\%$ of World Production \\
\hline United States & 60904.44 & 59719.73 & 52709.91 & $53 \%$ \\
\hline Brazil & 30242.15 & 32513.15 & 30015.05 & $30 \%$ \\
\hline European Union & 5488.25 & 5185.45 & 4731.25 & $5 \%$ \\
\hline China & 2914.45 & 3785 & 3330.8 & $3 \%$ \\
\hline Canada & 1741.1 & 1968.2 & 1619.98 & $2 \%$ \\
\hline India & 1627.55 & 1930.35 & 1949.275 & $2 \%$ \\
\hline Thailand & 1476.15 & 1627.55 & 1514 & $2 \%$ \\
\hline Argentina & 1097.65 & 1059.8 & 870.55 & $1 \%$ \\
\hline Australia & 250 & 247 & 235 & $<1 \%$ \\
\hline Rest of the world & 2002.265 & 1975.77 & 1892.5 & $<2 \%$ \\
\hline Total & 107744 & 110012 & 98868.32 & \\
\hline
\end{tabular}

\section{Conclusions and global trend forecast}

Biomass raw materials for ethanol production are mainly from three sources (a) sugar-bearing materials which contain carbohydrates in sugar form like sugarcane, sweet sorghum and molasses; (b) starches which contain carbohydrates in starch form such as corn, cassava, and potatoes and (c) celluloses whose carbohydrate form is more complex like wood and agricultural residues. The United States, Brazil, China, the European Union $(\mathrm{EU})^{*}$ and India are the top five leading ethanol producers in the world.

COVID-19 has hit the world and the production industries worldwide have been seriously affected. As a result, ethanol output worldwide has dropped since 2020. Other regions are being hit as well but their lower reliance on the fuel ethanol markets make the negative impact of the pandemic will be relatively less. When the pandemic is over and production industries get normal, it is expected that the rebound will come, however, the production might not be as strong as before the lock-down period worldwide. During the pandemic, even after the restrictions are eased, demand on the ethanol for hand-sanitiser manufacturing is high. In developing countries, stronger emissions regulations and policies help the production potential for biofuels increase to offset $\mathrm{CO}_{2}$ emissions. With an eye toward 2030, future ethanol will increase the share of total ethanol production worldwide.

\section{References}

1. Global Ethanol Production by Country or Region. Available online: https://afdc.energy.gov/data/10331/ (accessed on 19/9/2021). 
2. The Future of Biofuels: A Global Perspective. Available online: https://www.ers.usda.gov/amber-waves/2007/november/thefuture-of-biofuels-a-global-perspective/ (accessed on 19/9/2021).

3. Brazil Biofuels Annual Report 2016, Global Agricultural Information Network, Foreign Agricultural Service, U.S. Department of Agriculture, GAIN report number BR16009.

4. Drapcho, C.; Nghiem, N; Walker, T. Ethanol Production. In Biofuels Engineering Process Technology, 2nd ed.; McGraw-Hill: New York, USA, 2020; pp. 117-271.

5. Andrietta, S. R. and Maugeri, F. Optimum design of a continuous fermentation unit of an industrial plant for alcohol production, Advances in Bioprocess Engineering; E. Galindo and O. T. Ramirez (Eds.), Kluwer Academic Publishers, the Netherlands, 1994; pp. $47-52$.

6. España-Gamboa, L. et al., Vinasses: characterization and treatments, Waste Man. Res. 2011, 29, 1235-1250.

7. 2021 Ethanol Industry Outlook, Renewable Fuels Association. Available online: https://ethanolrfa.org/wp-content/uploads/2021/02/RFA_Outlook_2021_fin_low.pdf/ (accessed on 22/9/2021).

8. Enogen Corn for Ethanol. Available online: https://www.syngenta-us.com/corn/enogen/ (accessed on 22/9/2021).

9. TransFerm ${ }^{\circledR}$ Yield+. Available online: https://www.lallemandbds.com/products/transferm-yield/ (accessed on 22/9/2021).

10. Lallemand launches new Convergence yeast enzyme platform: could save ethanol producers $\$ 1 \mathrm{M} /$ year in replacing all external fermentation enzymes. Available online: https://www.biofuelsdigest.com/bdigest/2020/09/14/lallemand-launches-new-convergence-yeast-enzyme-platform-could-save-ethanol-producers-1m-year-in-replacing-all-external-fermentation-enzymes/ (accessed on 22/9/2021).

11. Novozymes adds yeast to the bioenergy business. Available online: https://www.novozymes.com/en/news/news-archive/2018/02/novozymes-adds-yeast-to-bioenergy-business/ (accessed on 22/9/2021).

12. Yeast for fermentation in bioenergy. Available online: https://biosolutions.novozymes.com/en/bioenergy/fermentation/ (accessed on 22/9/2021).

13. D3MAX. Available online: https://www.d3maxllc.com/technology/ (accessed on 22/9/2021).

14. Available online: https://ethanol.org/Delayne Johnson Quiet Ingenuity.pdf/ (accessed on 22/9/2021).

15. Available online: http://ethanolproducer.com/articles/16203/california-certifies-2-plants-for-corn-kernel-fiber-ethanol/ (accessed on 22/9/2021).

16. Intellulose: An Innovative Approach to Your Plant's Profitability. Available online: https://distillersgrains.org/wp-content/uploads/2019/05/7-Kacmar-Intellulose.pdf/ (accessed on 22/9/2021).

17. Farone, W. A. and Cuzens, J. E. Method of producing sugars using strong acid hydrolysis of cellulosic and hemicellulosic materials, 2016, US 5,562,777.

18. Groenestijn, J. W. et al. Pre-treatment of lingo-cellulose with biological acid recycling (the Biosulfurol process), Int. Sugar J. 2008, 110, 689-692.

19. Kilambi, S. and Kadam, K. L. Production of fermentable sugars and lignin from biomass using supercritical fluids, 2013, U. S. 2013/0239954.

20. Dumesic, J. A. et al. 2013, Production of levulinic acid, furfural, and gamma-valerolactone from C5 and C6 carbohydrates in mono- and biphasic systems using gamma-valerolactone as a solvent, 2013, US 8,399,688.

21. Available online: https://www.lallemandbds.com/wp-content/uploads/2015/06/Xyloferm-product-sheet-2016-05-19.pdf/ (accessed on 22/9/2021).

22. OECD-FAO Agricultural Outlook 2021-2030. Available online: https://www.fao.org/publications/oecd-fao-agricultural-outlook/2021-2030/en/ (accessed on 12/10/2021).

23. 2020 Ethanol Industry Outlook, Renewable Fuels Association. Available online: https://ethanolrfa.org/file/21/2020-Outlook-Final-for-Website.pdf/ (accessed on 12/10/2021).

24. New Energy Blue to construct cellulosic biorefinery in Iowa. Available online: http://biomassmagazine.com/articles/18180/newenergy-blue-to-construct-cellulosic-biorefinery-in-iowa/ (accessed on 12/10/2021).

25. Inbicon Biomass Refinery. Available online: https:/www.eia.gov/biofuels/workshop/pdf/paul_kamp.pdf/ (accessed on 12/10/2021).

26. Brazil Biofuels Annual Report 2020, Global Agricultural Information Network, Foreign Agricultural Service, U.S. Department of Agriculture, GAIN report number BR2020-0032.

27. Argentina Biofuels Annual Report 2020, Global Agricultural Information Network, Foreign Agricultural Service, U.S. Department of Agriculture, GAIN report number AR2020-0027.

28. Colombia Biofuels Annual Report 2021, Global Agricultural Information Network, Foreign Agricultural Service, U.S. Department of Agriculture, GAIN report number CO2021-0012.

29. European Union Biofuels Annual Report 2021, Global Agricultural Information Network, Foreign Agricultural Service, U.S. Department of Agriculture, GAIN report number E42021-0053.

30. Duy Nong, CanWangcAbul, QuasemAl-Aminde, A critical review of energy resources, policies and scientific studies towards a cleaner and more sustainable economy in Vietnam, Renewable and Sustainable Energy Reviews, Volume 134, December 2020, 110117.

31. Vietnam Ethanol Background Report I USDA Foreign ...." 11 Aug. 2020, https://www.fas.usda.gov/data/vietnam-vietnam-ethanol-background-report. Accessed 18 May. 2021.

32. Jun-SeokKima, Production of bioethanol from lignocellulose: Status and perspectives in Korea, Bioresource Technology, Volume 101, Issue 13, July 2010, Pages 4801-4805. 
33. Reuter's report, China set to triple its ethanol production capacity: government.... availabe at https://www.reuters.com/article/us-china-ethanol/china-set-to-triple-its-ethanol-production-capacity-government-researcher-idUSKBN1OA0FH. Accessed 21 May. 2021.

34. USDA's China biofuel annual, https://www.fas.usda.gov/data/china-biofuels-annual-6.

35. USDA's India biofuel annual, Biofuels Annual, https://www.fas.usda.gov/data/india-biofuels-annual-6.

36. USDA's Thailand biofuel annual, https://www.fas.usda.gov/data/thailand-biofuels-annual-4.

37. USDA's Australia biofuel annual, https://www.fas.usda.gov/data/australia-biofuels-annual.

38. Bioethanol in africa: the case for technology transfer and south-south cooperation, 2016, https://www.irena.org/-/media/Files/IRENA/Agency/Publication/2016/IRENA_Bioethanol_in_Africa_2016.pdf.

39. ValerieThomas, AndrewKwong, Ethanol as a lead replacement: phasing out leaded gasoline in Africa, Energy Policy, Volume 29, Issue 13, November 2001, Pages 1133-1143.

40. Pobitra Halde et al, Prospects and technological advancement of cellulosic bioethanol ecofuel production, Advances in EcoFuels for a Sustainable Environment, Woodhead Publishing Series in Energy 2019, Pages 211-236.

41. Renewable Fuels Association analysis of public and private data, availabe onlie: https://ethanolrfa.org/marketsand-statistics/annual-ethanol-production. 